\title{
Model Prototipe dan Analisis Use Case pada Rekayasa Kebutuhan Perangkat Lunak Pengajuan Dokumen Kependudukan
}

\author{
Anggi Perwitasari ${ }^{\# 1}$, M. Azhar Irwansyah ${ }^{\# 2}$ \\ ${ }^{\#}$ Jurusan Informatika, Fakultas Teknik, Universitas Tanjungpura \\ Jl. Prof. Dr. Hadari Nawawi, Pontianak, Kalimantan Barat \\ ${ }^{1}$ anggiperwitasari@informatika.untan.ac.id \\ 2irwansyah.azhareuntan.ac.id
}

\begin{abstract}
Abstrak - Penelitian ini menggunakan model prototipe dan analisis use case sebagai pendekatan dalam rekayasa kebutuhan perangkat lunak pengajuan dokumen kependudukan. Sebuah rangkaian fase iteratif prototipe dan analisis use case untuk rekayasa kebutuhan perangkat lunak pengajuan dokumen kependudukan dideskripsikan. Tujuan penggunaan model prototipe dan analisis use case ini yaitu untuk menangkap kebutuhan perangkat lunak dari beragam stakeholder, dan membantu stakeholder memahami setiap fungsi dengan mudah, memberikan evaluasi dengan cepat dan membantu pihak pengembang mendokumentasikan kebutuhan dengan cepat. Penelitian ini menghasilkan 12 (dua belas) kebutuhan awal, 12 (dua belas) prototipe serta 14 (empat belas) spesifikasi kebutuhan perangkat lunak. Seluruh prototipe telah dievaluasi dan memenuhi seluruh kebutuhan pengguna dan fungsionalitas berdasarkan evaluasi dengan traceability matrix. Spesifikasi kebutuhan perangkat lunak pengajuan dokumen kependudukan yang dihasilkan dapat digunakan dalam pengembangan aplikasi pengajuan dokumen kependudukan sebagai rekomendasi penelitian kedepannya.
\end{abstract}

Kata kunci- Rekayasa Kebutuhan, Prototipe, Use Case, Traceability Matrix, Dokumen Kependudukan.

\section{PEndahuluan}

Kebutuhan perangkat lunak merupakan atribut yang diperlukan dalam suatu sistem, sebuah pernyataan yang mengidentifikasi kemampuan, karakteristik, atau faktor kualitas suatu sistem agar memiliki nilai dan kegunaan bagi pelanggan atau pengguna. Kebutuhan penting dalam menyediakan dasar untuk semua pekerjaan pengembangan perangkat lunak berikutnya[1].

Hal yang paling menarik sekaligus sulit dalam proses pengembangan perangkat lunak adalah menyatukan perspektif terkait kebutuhan perangkat lunak antara pelanggan, pengguna akhir, stakeholder dan pengembang. Masalah komunikasi menjadi kendala besar dalam penentuan kebutuhan perangkat lunak ketika tim pengembang perangkat lunak, analis sistem berbicara dalam istilah teknis, sedangkan stakeholder berbicara dalam konteks bisnis mereka, sehingga hasil analisis tidak memberikan ekspektasi yang sesuai dengan harapan pelanggan. Untuk itu, model prototipe dapat digunakan untuk mengurangi celah ketidakpahaman pelanggan mengenai hal teknis dan memperjelas spesifikasi kebutuhan yang diinginkan pelanggan kepada pengembang perangkat lunak[2]

Prototipe merupakan model pengembangan perangkat lunak yang digunakan untuk meminimalisir kesalahpahaman antara stakeholder dan analis yang timbul akibat stakeholder tidak mampu mendefinisikan secara jelas kebutuhannya[3]. Model ini merupakan solusi yang mampu memperkecil celah kesalahan dalam komunikasi antara analis sistem dan stakeholder[4]. Prototipe perangkat lunak dapat digunakan dalam proses pengembangan perangkat lunak untuk membantu mengantisipasi perubahan yang mungkin diperlukan dalam proses rekayasa kebutuhan yaitu membantu elisitasi dan validasi kebutuhan sistem[5].

Dalam penelitian ini dilakukan rangkaian model prototipe dan analisis dengan use case dalam proses rekayasa kebutuhan. Rekayasa kebutuhan dilakukan pada kasus pengembangan perangkat lunak pengajuan dokumen kependudukan di Disdukcapil (Dinas Kependudukan dan Catatan Sipil) Kabupaten Sambas, Kalimantan Barat. Dokumen kependudukan merupakan dokumen resmi yang diterbitkan oleh Instansi Pelaksana yang mempunyai kekuatan hukum sebagai alat bukti autentik yang dihasilkan dari pelayanan Pendaftaran Penduduk dan Pencatatan Sipil[6]. Proses pengajuan dokumen kependudukan diharapkan dapat dilakukan melalui sebuah perangkat lunak yang dapat diakses oleh seluruh masyarakat desa yang berada pada wilayah Kabupaten Sambas. Proses rekayasa kebutuhan melibatkan stakeholder dari masyarakat Desa Sanatab, Kecamatan dan Disdukcapil Kabupaten Sambas, untuk menghasilkan spesifikasi kebutuhan perangkat lunak pengajuan dokumen kependudukan. 


\section{LITERATUR REVIEW}

Dalam penelitian yang dilakukan oleh Markus Mannio dan Uilevi Nikula[7] yaitu melakukan pengumpulan kebutuhan dengan menerapkan kombinasi antara model prototipe dan skenario, penelitian ini dilaksanakan dengan melakukan demonstrasi model prototipe secara berulang serta menyajikan prototipe berdasarkan pada use case yang dibuat. Manfaat dari metode ini yaitu untuk membantu dalam menangkap kebutuhan yang berkualitas dari kumpulan stakeholder yang beragam. Dalam penelitian ini sebuah studi kasus sederhana digunakan untuk mendemonstrasikan model ini.

Pada penelitian yang dilakukan oleh Siti Sauda dan Eka Puji Agustini, model prototipe diimplementasikan dalam pengembangan aplikasi Smart Cleaning sebagai pendukung aplikasi Smart City[8]. Model prototipe dilakukan secara iterasi dengan 6 (enam) proses yaitu: (1) Pengumpulan Kebutuhan; (2) Desain Cepat; (3) Membangun prototipe; (4) Evaluasi prototipe; (5) Perbaikan prototipe; dan (5) Rekayasa produk. Selain itu penggunaan UML juga dilakukan untuk melengkapi dokumentasi atau wujud dari blueprint.

Berdasarkan pada dua penelitian diatas, proses pengumpulan kebutuhan dan pengembangan perangkat lunak dapat dilakukan dengan menggabungkan dua model yakni model prototipe dan analisis menggunakan use case. Penggunaan prototipe diharapkan memberikan gambaran terhadap produk perangkat lunak yang dihasilkan dan analisis usecase diharapkan memberikan pemahaman bagi stakeholder dalam memfungsikan produk prototipe, memahami fungsionalitas dari prototipe, dan memudahkan pengembang dalam menangkap kebutuhan dari stakeholder. Untuk itu, research question pada penelitian ini yaitu:

- Bagaimana model prototipe dan use case dapat diterapkan dalam rekayasa kebutuhan perangkat lunak studi kasus perangkat lunak pengajuan dokumen kependudukan?

- Dalam studi kasus yang diberikan, apakah prototipe yang dihasilkan memenuhi kebutuhan pengguna?

- Bagaimana spesifikasi kebutuhan perangkat lunak yang dihasilkan?

\section{METODOLOGI}

Rekayasa kebutuhan dengan model prototipe yang dilakukan merupakan pengembangan dari model prototipe milik Pressman yang terdiri dari proses komunikasi, membangun perencanaan dan desain secara cepat, mengembangkan prototipe, kemudian memberikan hasil kepada stakeholder untuk memperoleh umpan balik sebagai dasar dalam pengembangan kebutuhan[9].

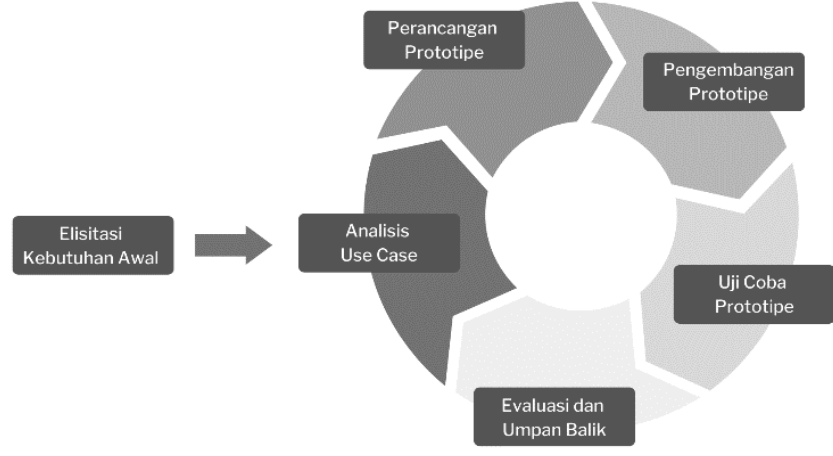

Gambar. 1 Fase rekayasa kebutuhan prototipe

Model ini akan mengkolaborasikan model prototipe pada penelitian pengembangan aplikasi Smart Cleaning milik Siti Sauda dan Eka Puji Agustini[8] serta analisis use case pada penelitian Markus Mannio dan Uilevi Nikula[7] untuk melakukan rekayasa kebutuhan perangkat lunak. Fase model prototipe dan analisis use case yang digunakan dalam rekayasa kebutuhan perangkat lunak pengajuan dokumen kependudukan terlihat pada gambar 1

\section{A. Elisitasi Kebutuhan Awal}

Pada fase ini, dilakukan proses elisitasi kebutuhan pengguna dengan menerapkan teknik pengumpulan informasi meliputi wawancara, observasi dan kajian dokumen standar operasional prosedur. Tahap ini bertujuan untuk mengidentifikasi kelas pengguna/entitas/objek serta stakeholder yang terlibat pada sistem dan kebutuhan pengguna dari sudut pandang pelanggan yang seringkali menghasilkan ketidaksesuaian antara produk yang diharapkan pelanggan dan apa yang dibuat oleh pengembang[10].

\section{B. Analisis Use case}

Pada fase ini, dilakukan analisis dengan pemodelan use case. Fase ini akan dilakukan untuk melakukan pemodelan fungsionalitas dari sistem[11]. Use case akan digunakan dalam proses pemodelan fungsionalitas suatu sistem atau kelas dan bagaimana sistem ini berinteraksi dengan dunia luar. Use case diagram dapat digunakan untuk memperoleh kebutuhan sistem dan memahami bagaimana sistem seharusnya bekerja[12].

Pemodelan use case biasanya digunakan dari awal proyek dan terus berlanjut hingga proses pengembangan sistem. Fase ini akan berkembang seiring dengan lahirnya ide-ide yang berhasil dieksplorasi oleh stakeholder dan analis sistem dalam penyempurnaan kebutuhan.

\section{Perancangan Prototipe dan Pengembangan Prototipe}

Prototipe adalah bagian dari produk yang mengekspresikan logika dan antarmuka eksternal fisik yang ditampilkan. Pelanggan kemudian menggunakan prototipe dan memberikan masukan kepada tim pengembangan sebelum pengembangan skala besar dimulai[13]. Pada fase perancangan prototipe, dilakukan 
perancangan prototipe berdasarkan kebutuhan awal dan hasil analisis use case yang diperoleh. Proses perancangan akan didasari pada setiap entitas/objek/kelas pengguna yang terlibat didalam sistem serta fungsionalitas yang dimiliki sistem untuk menghasilkan daftar kelas yang digunakan sebagai dasar pengembangan prototipe.

Pada fase pengembangan prototipe dilakukan proses implementasi terhadap rancangan prototipe. Prototipe yang dihasilkan akan menyajikan seluruh fungsionalitas yang telah didefinisikan dengan bentuk yang sederhana. Setiap prototipe dipisahkan dan diberi penamaan sesuai dengan fungsi-fungsinya. Hal ini untuk memudahkan stakeholder dalam proses uji coba prototipe untuk menentukan apakah prototipe yang dihasilkan sudah memenuhi kebutuhan atau diperlukan modifikasi.

\section{Uji Coba Prototipe}

Fase ini dilakukan proses uji coba prototipe yang telah dihasilkan oleh stakeholder. Proses ini dilakukan untuk menangkap pandangan dari stakeholder serta menangkap kebutuhan perangkat lunak[7]. Tahap ini dilakukan dengan melaksanakan pertemuan antara pengembang dan stakeholder, menampilkan prototipe pada sebuah layar proyektor untuk dievaluasi secara bersama.

\section{E. Evaluasi dan Umpan Balik}

Fase ini ini merupakan fase yang dilakukan bersamaan dengan fase uji coba prototipe. Pada Fase ini pengguna memberikan melakukan evaluasi dan memberikan umpan balik berupa perubahan pada prototipe. Berdasarkan umpan balik ini, daftar kebutuhan terus disempurnakan sesuai kebutuhan pengguna. Proses penyempurnaan dilakukan berulang kali hingga pengguna benar-benar nyaman dalam pengoperasian sistem yang dibangun dan memenuhi kebutuhan.

Fase evaluasi dan umpan balik merupakan fase penentu apakah prototipe akan masuk ke dalam fase rekayasa produk atau fase pembuatan sistem. Fase ini adalah fase yang menentukan apakah diperlukan modifikasi terhadap kebutuhan perangkat lunak yang telah didefinisikan[7].

\section{HASIL DAN PEMBAHASAN}

Penelitian ini menggabungkan beberapa teknik dalam memperoleh informasi meliputi wawancara, observasi sistem dispendukcapil Kota Surakarta, serta kajian terhadap dokumen standar operasional prosedur dalam pengajuan dokumen kependudukan. Dalam proses rekayasa kebutuhan perangkat lunak, peneliti menggunakan pendekatan prototipe dan analisis dengan use case diagram dengan harapan dapat menangkap kebutuhan dari stakeholder yang bergam dan meminimalisir ketidakpahaman dan memperjelas kebutuhan yang diinginkan pelanggan kepada pengembang.

Proses rekayasa kebutuhan perangkat lunak dokumen kependudukan ini dilakukan dengan pendekatan prototipe dan analisis use case serta melibatkan beragam stakeholder antara lain: Disdukcapil Kabupaten Sambas; masyarakat di Desa Sanatab; serta pegawai di Kantor Desa dan
Kecamatan. Berikut adalah hasil dan pembahasan pada setiap fase yang telah dilaksanakan

\section{A. Elisitasi Kebutuhan Awal}

Proses elisitasi kebutuhan merupakan proses komunikasi awal yang dilakukan pengembang kepada stakeholder dari Disdukcapil Kabupaten Sambas, masyarakat di Desa Sanatab dan pegawai di Kantor Desa dan Kecamatan. Proses elisitasi kebutuhan awal ini dilakukan dengan wawancara dengan stakeholder yang berbeda dalam tiga sesi. Stakeholder telah dipilih berdasarkan keterlibatannya dalam proses pengajuan dokumen kependudukan. Pada level Disdukcapil, dipilih stakeholder dari bagian pelayanan (front office) yang terlibat pemrosesan pelayanan pengajuan pemrosesan surat (validasi berkas dan kelengkapan) dan pemberian dokumen kependudukan, bagian pendataan dan pencetakan dokumen, dan pihak yang berwenang menandatangani dokumen, Sedangkan di level masyarakat, pegawai Kantor Desa dan Kecamatan adalah individu yang pernah menjadi pemohon/ pernah membantu dalam proses pengajuan dokumen kependudukan. Proses elisitasi kemudian menghasilkan dokumentasi berupa rekaman jawaban atas daftar pertanyaan wawancara yang dijadikan dasar dalam pengembangan spesifikasi kebutuhan pengguna [14]

TABEL I

DAFTAR KEBUTUHAN PENGGUNA

\begin{tabular}{|c|c|c|}
\hline Req Code & Stakeholder & Description \\
\hline $\mathrm{KP}-001$ & \multirow[t]{5}{*}{ Pemohon } & $\begin{array}{l}\text { Dapat mengajukan permohonan } \\
\text { pembuatan dokumen penduduk } \\
\text { secara online }\end{array}$ \\
\hline $\mathrm{KP}-002$ & & $\begin{array}{l}\text { Dapat mengirimkan seluruh } \\
\text { berkas persyaratan dalam bentuk } \\
\text { digital secara online }\end{array}$ \\
\hline $\mathrm{KP}-003$ & & $\begin{array}{lll}\text { Dapat mengetahui } & \text { kapan } \\
\text { dokumen yang diajukan dapat } \\
\text { diambil di Kantor Disdukcapil }\end{array}$ \\
\hline $\mathrm{KP}-004$ & & $\begin{array}{l}\text { Dapat mengajukan pencetakan } \\
\text { ulang dokumen kependudukan } \\
\text { yang hilang. }\end{array}$ \\
\hline $\mathrm{KP}-005$ & & $\begin{array}{l}\text { Dapat mengetahui berkas } \\
\text { persyaratan yang dibutuhkan }\end{array}$ \\
\hline $\mathrm{KP}-006$ & \multirow[t]{7}{*}{ Disdukcapil } & $\begin{array}{l}\text { Pengisian seluruh formulir untuk } \\
\text { pengajuan dokumen } \\
\text { kependudukan dilakukan secara } \\
\text { online }\end{array}$ \\
\hline $\mathrm{KP}-007$ & & $\begin{array}{l}\text { Dapat melihat seluruh dokumen } \\
\text { persyaratan untuk divalidasi }\end{array}$ \\
\hline $\mathrm{KP}-008$ & & $\begin{array}{l}\text { Membuat antrian pengambilan } \\
\text { dokumen kependudukan secara } \\
\text { otomatis }\end{array}$ \\
\hline $\mathrm{KP}-009$ & & $\begin{array}{ll}\text { Menginformasikan } & \text { jadwal } \\
\text { pengambilan dokumen } & \text { kepada } \\
\text { pemohon } & \end{array}$ \\
\hline $\mathrm{KP}-010$ & & $\begin{array}{l}\text { Memproses dokumen yang } \\
\text { persyaratannya lengkap }\end{array}$ \\
\hline $\mathrm{KP}-011$ & & $\begin{array}{l}\text { Membatalkan pengajuan dokumen } \\
\text { dan menginfokan alasan } \\
\text { pembatalan kepada pemohon }\end{array}$ \\
\hline $\mathrm{KP}-012$ & & $\begin{array}{l}\text { Menyimpan berkas pesyaratan } \\
\text { milik pemohon secara digital }\end{array}$ \\
\hline
\end{tabular}


Selain itu, untuk mendukung identifikasi entitas/kelas pengguna serta kebutuhan awal pengguna, dilakukan teknik observasi terhadap sistem milik Dinas Kependudukan dan Catatn Sipil Kota Surakarta serta kajian dokumen standar operasional prosedur milik Disdukcapil Kabupaten Sambas yang meliputi pengajuan dokumen Kartu Tanda Penduduk (KTP), Kartu Identitas Anak (KIA), Kartu Keluarga (KK), Akta Kelahiran, dan Akta Kematian. Dalam elisitasi kebutuhan berhasil diidentifikasi 2 (dua) entitas/kelas pengguna yakni masyarakat dan Disdukcapil serta 12 (dua belas) kebutuhan pengguna terkait pengajuan dokumen kependudukan.

Dalam proses wawancara di level pemohon cenderung menyampaikan kebutuhan secara umum. Sedangkan pada level Disdukcapil, kebutuhan pengguna disampaikan secara spesifik. Dalam proses wawancara ini, pihak Disdukcapil menjadi pihak yang dianggap paling memahami proses pengajuan dokumen, sehingga proses wawancara dilaksanakan dalam 2 (dua) sesi dan 1 (satu) sesi wawancara kepada pemohon.

\section{B. Analisis Use case}

Pada fase ini dilakukan pemodelan use case berdasarkan pada daftar kebutuhan pengguna yang diperoleh pada fase elisitasi kebutuhan dan dilakukan analisis dengan use case. Pada proses analisis use case dilakukan perluasan dua fungsionalitas yang terkait dengan perangkat lunak meliputi pembagian hak akses pengguna (Pemohon dan Disdukcapil) dan perluasan lainnya berdasarkan observasi dan kajian dokumen standar operasional prosedur. Proses analisis use case dilakukan oleh analis sistem dan selanjutnya digunakan sebagai dasar dalam perancangan dan pengembangan prototipe. Terdapat 14 (empat belas) use case yang berhasil dianalisis pada tabel II.

TABEL III

USE CASE DESCRIPTION

\begin{tabular}{|c|c|c|c|}
\hline $\begin{array}{l}\text { Use } \\
\text { case } \\
\text { Code }\end{array}$ & $\begin{array}{c}\text { Use case } \\
\text { Name }\end{array}$ & Actor & Description \\
\hline $\mathrm{UC}-001$ & Registrasi & Pemohon & $\begin{array}{l}\text { Registrasi dilakukan } \\
\text { dengan email atau } \\
\text { NIK (jika telah } \\
\text { memiliki KTP) }\end{array}$ \\
\hline $\mathrm{UC}-002$ & $\begin{array}{l}\text { Autentikasi } \\
\text { Pengguna }\end{array}$ & $\begin{array}{l}\text { Pemohon, } \\
\text { Disdukcapil }\end{array}$ & $\begin{array}{l}\text { Pembagian hak } \\
\text { akses pengguna } \\
\text { terhadap sistem }\end{array}$ \\
\hline $\mathrm{UC}-003$ & $\begin{array}{l}\text { Mengisi Form } \\
\text { Pengajuan } \\
\text { Dokumen } \\
\text { Kependudukan } \\
\text { Baru / Hilang }\end{array}$ & Pemohon & $\begin{array}{l}\text { Mengisikan data } \\
\text { pada formulir } \\
\text { pengajuan dokumen } \\
\text { KTP, KK, KIA, akta } \\
\text { kelahiran dan akta } \\
\text { kematian }\end{array}$ \\
\hline $\mathrm{UC}-004$ & $\begin{array}{l}\text { Unggah } \\
\text { Berkas } \\
\text { Persyaratan }\end{array}$ & Pemohon & $\begin{array}{l}\text { Mengunggah } \\
\text { seluruh dokumen } \\
\text { persyaratan dalam } \\
\text { pembuatan } \\
\text { dokumen baru / } \\
\text { hilang }\end{array}$ \\
\hline $\mathrm{UC}-005$ & $\begin{array}{l}\text { Unduh Bukti } \\
\text { Pengambilan } \\
\text { dokumen }\end{array}$ & Pemohon & $\begin{array}{lr}\text { Mengunduh } & \text { bukti } \\
\text { dan } & \text { waktu } \\
\text { pengambilan } & \\
\text { dokumen } & \\
\end{array}$ \\
\hline
\end{tabular}

\begin{tabular}{|c|c|c|c|}
\hline $\begin{array}{l}\text { Use } \\
\text { case } \\
\text { Code }\end{array}$ & $\begin{array}{l}\text { Use case } \\
\text { Name }\end{array}$ & Actor & Description \\
\hline $\mathrm{UC}-006$ & $\begin{array}{l}\text { Lihat data } \\
\text { pemohon }\end{array}$ & $\begin{array}{l}\text { Pemohon, } \\
\text { Disdukcapil }\end{array}$ & $\begin{array}{l}\text { Melihat data } \\
\text { pemohon pengajuan } \\
\text { dokumen }\end{array}$ \\
\hline $\mathrm{UC}-007$ & $\begin{array}{l}\text { Validasi } \\
\text { berkas } \\
\text { pesyaratan } \\
\end{array}$ & Disdukcapil & $\begin{array}{lr}\text { Melihat } & \text { berkas } \\
\text { pesyaratan } & \text { yang } \\
\text { diunggah pemohon }\end{array}$ \\
\hline $\mathrm{UC}-008$ & $\begin{array}{l}\text { Lihat Info } \\
\text { Berkas } \\
\text { Persyaratan } \\
\end{array}$ & $\begin{array}{l}\text { Pemohon, } \\
\text { Disdukcapil }\end{array}$ & $\begin{array}{lr}\begin{array}{l}\text { Melihat } \\
\text { persyaratan } \\
\text { dibutuhkan }\end{array} & \begin{array}{r}\text { berkas } \\
\text { yang }\end{array} \\
\end{array}$ \\
\hline $\mathrm{UC}-009$ & $\begin{array}{l}\text { Melihat daftar } \\
\text { pengajuan } \\
\text { dokumen } \\
\text { lengkap }\end{array}$ & Disdukcapil & $\begin{array}{l}\text { Melihat daftar } \\
\text { pengajuan dokumen } \\
\text { dengan persyaratan } \\
\text { lengkap }\end{array}$ \\
\hline $\mathrm{UC}-010$ & $\begin{array}{l}\text { Mengelola } \\
\text { berkas } \\
\text { persyaratan }\end{array}$ & Disdukcapil & $\begin{array}{lr}\text { Melihat } & \text { dan } \\
\text { mengunduh } & \text { berkas } \\
\text { persyaratan } & \\
\text { pemohon } & \\
\end{array}$ \\
\hline $\mathrm{UC}-011$ & $\begin{array}{l}\text { Memproses } \\
\text { pengajuan }\end{array}$ & Disdukcapil & $\begin{array}{ll}\text { Mengubah } & \text { status } \\
\text { permohonan } & \text { untuk } \\
\text { diproses } & \\
\end{array}$ \\
\hline $\mathrm{UC}-012$ & $\begin{array}{l}\text { Membatalkan } \\
\text { pengajuan }\end{array}$ & Disdukcapil & $\begin{array}{l}\text { Pembatalan } \\
\text { permohonan alasan } \\
\text { pembatalan }\end{array}$ \\
\hline $\mathrm{UC}-013$ & $\begin{array}{l}\text { Membuat } \\
\text { Nomor } \\
\text { Antrian }\end{array}$ & Disdukcapil & $\begin{array}{l}\text { Membuat nomor } \\
\text { antrian dan }\end{array}$ \\
\hline $\mathrm{UC}-014$ & $\begin{array}{l}\text { Membuat } \\
\text { jadwal } \\
\text { pengambilan } \\
\text { dokumen }\end{array}$ & Disdukcapil & $\begin{array}{l}\text { Membuat jadwal } \\
\text { pengambilan } \\
\text { dokumen secara } \\
\text { otomatis }\end{array}$ \\
\hline
\end{tabular}

\section{Perancangan Prototipe dan Pengembangan Prototipe}

Berdasarkan hasil analisis dengan use case, dilakukan perancangan dan pengembangan prototipe secara cepat dan menghasilkan 12 (dua belas) prototipe yang digunakan dalam proses pengumpulan kebutuhan perangkat lunak pengajuan dokumen kependudukan. Prototipe dirancang dan dikembangkan secara sederhana berdasarkan fungsifungsi yang didefinisikan pada use case dan berhasil dikembangkan dengan bahasa pemrograman php dan html dan basis data MySQL. Prototipe yang dihasilkan lebih mengutamakan aspek fungsionalitas dan belum mempertimbangkan aspek keramahan pengguna maupun desain antarmuka.

TABEL IIIII

DAFTAR PROTOTIPE

\begin{tabular}{|l|l|l|}
\hline $\begin{array}{c}\text { Prototype } \\
\text { Code }\end{array}$ & \multicolumn{1}{|c|}{ Class Name } & \multicolumn{1}{|c|}{ Functionality } \\
\hline $\mathrm{CP}-001$ & Registration & Registrasi pengguna \\
\hline $\mathrm{CP}-002$ & Authentication & Autentikasi pengguna \\
\hline $\mathrm{CP}-003$ & IdCardSubmission & $\begin{array}{l}\text { Form isian data } \\
\text { pengajuan KTP Baru / } \\
\text { Hilang }\end{array}$ \\
\hline $\mathrm{CP}-004$ & FamCardSubmission & $\begin{array}{l}\text { Form isian data } \\
\text { pengajuan KK Baru / } \\
\text { Hilang }\end{array}$ \\
\hline $\mathrm{CP}-005$ & BirthCertSubmission & $\begin{array}{l}\text { Form isian data } \\
\text { pengajuan Akta } \\
\text { Kelahiran Baru / Hilang }\end{array}$ \\
\hline $\mathrm{CP}-006$ & DeathCertSubmission & $\begin{array}{l}\text { Form isian data } \\
\text { pengajuan Akta } \\
\text { kematian Baru / Hilang }\end{array}$ \\
\hline
\end{tabular}




\begin{tabular}{|c|c|c|}
\hline $\begin{array}{c}\text { Prototype } \\
\text { Code }\end{array}$ & Class Name & Functionality \\
\hline $\mathrm{CP}-007$ & ChildIdCardSubmission & $\begin{array}{l}\text { Form isian data } \\
\text { pengajuan KIA Baru / } \\
\text { Hilang }\end{array}$ \\
\hline $\mathrm{CP}-008$ & DocumentRequirement & $\begin{array}{l}\text { Mengelola data berkas, } \\
\text { Mengunggah } \\
\text { mengunduh } \\
\text { persyaratan }\end{array}$ \\
\hline $\mathrm{CP}-009$ & Applicant & $\begin{array}{l}\text { Melihat data pemohon, } \\
\text { daftar pengajuan } \\
\text { dokumen oleh pemohon }\end{array}$ \\
\hline $\mathrm{CP}-010$ & SubmissionInfo & $\begin{array}{l}\text { Melihat daftar } \\
\text { pengajuan, daftar berkas } \\
\text { persyaratan, validasi } \\
\text { berkas persyaratan, serta } \\
\text { melihat dan mengubah } \\
\text { status pengajuan }\end{array}$ \\
\hline $\mathrm{CP}-011$ & SubmissionQueue & $\begin{array}{l}\text { Generate antrian } \\
\text { otomatis, dan Jadwal } \\
\text { pengambilan berkas }\end{array}$ \\
\hline $\mathrm{CP}-012$ & Dashboard & $\begin{array}{lr}\text { Melihat } & \text { daftar } \\
\text { pengajuan dokumen } \\
\text { yang masuk, daftar } \\
\text { pengajuan dengan } \\
\text { persyaratan lengkap } \\
\text { melihat jadwal } \\
\text { pengambilan dokumen, } \\
\text { status pengajuan, dan } \\
\text { info berkas persyaratan }\end{array}$ \\
\hline
\end{tabular}

\section{Uji Coba Prototipe}

Fase uji coba dilakukan oleh pengembang dan pengguna yang telah berhasil didefinisikan pada fase elisitasi kebutuhan yakni masyarakat di Desa Sanatab dan pihak disdukcapil Kabupaten Sambas. Pada fase ini, 12 (dua belas) prototipe yang dihasilkan, difungsikan secara bersamasama pada sebuah layar proyektor.

Sebelum memulai uji coba, seorang sistem analis akan menyampaikan alur uji coba, memperkenalkan apa itu prototipe, daftar kebutuhan, use case dan kegunaan dari ketiganya. Dalam proses uji coba, setiap use case akan ditampilkan dan digunakan dalam mempraktekan penggunaan prototipe, agar pengguna memahami cara kerja dari prototipe yang dihasilkan. Proses uji coba terhadap prototipe dilakukan dalam beberapa iterasi berdasarkan pada adanya modifikasi terhadap kebutuhan yang berhasil ditangkap dari proses uji coba.

Setiap proses uji coba akan menghasilkan sebuah dokumen checklist untuk menyimpulkan apakah prototipe yang diuji cobakan telah memenuhi kebutuhan pengguna. Setiap pelaksanaan uji coba prototipe telah selesai dilakukan, dilakukan proses evaluasi dari pengguna dan analis akan mendokumentasikan umpan balik dari pengguna terkait adanya modifikasi atau perubahan prototipe yang diperlukan.

\section{E. Evaluasi dan Umpan Balik}

Proses evaluasi dilakukan setelah proses uji coba diselesaikan. Pada tahap ini seluruh dokumentasi kebutuhan pengguna berupa checklist dievaluasi kembali untuk memastikan apakah diperlukan proses modifikasi atau pengembangan terhadap kebutuhan pengguna. Proses evaluasi dilakukan dengan melakukan pelacakan terhadap kebutuhan pengguna terhadap fungsionalitas/fitur dari prototipe yang dihasilkan.

Untuk melakukan pelacakan kebutuhan dan fitur ini, bisa dibuat sebuah tabel yang bernama traceability matrix [15]. Evaluasi traceability matrix untuk menentukan apakah semua kebutuhan pengguna sudah terdefinisi dengan baik ke dalam rancangan prototipe yang dihasilkan[16]. Berdasarkan pemetaan kebutuhan dalam traceability matrix, seluruh prototipe telah memenuhi seluruh kebutuhan pengguna yang didefinisikan dan 14 (empat belas) fungsionalitas pada use case. Hasil evaluasi oleh stakeholder dan analis sistem berdasarkan pada traceability matrix memperoleh 14 (empat belas) spesifikasi kebutuhan perangkat lunak yang merupakan kebutuhan fungsional dari aplikasi pengajuan dokumen

TABEL IVV

PemetaAn Prototipe Terhadap Kebutuhan PengGuna

\begin{tabular}{|l|l|}
\hline \multicolumn{1}{|c|}{ Req Code } & \multicolumn{1}{|c|}{ Prototype Code } \\
\hline $\mathrm{KP}-001$ & $\begin{array}{l}\text { CP-003, CP-004, CP-005, } \\
\text { CP-006, CP-007 }\end{array}$ \\
\hline $\mathrm{KP}-002$ & $\mathrm{CP}-008$ \\
\hline $\mathrm{KP}-003$ & $\mathrm{CP}-010, \mathrm{CP}-011$ \\
\hline $\mathrm{KP}-004$ & $\begin{array}{l}\text { CP-003, CP-004, CP-005, } \\
\text { CP-006, CP-007 }\end{array}$ \\
\hline $\mathrm{KP}-005$ & $\mathrm{CP}-012$ \\
\hline $\mathrm{KP}-006$ & $\begin{array}{l}\text { CP-003, CP-004, CP-005, } \\
\text { CP-006, CP-007 }\end{array}$ \\
\hline $\mathrm{KP}-007$ & $\mathrm{CP}-008, \mathrm{CP}-010$ \\
\hline $\mathrm{KP}-008$ & $\mathrm{CP}-011$ \\
\hline $\mathrm{KP}-009$ & $\mathrm{CP}-011, \mathrm{CP}-012$ \\
\hline $\mathrm{KP}-010$ & $\mathrm{CP}-010, \mathrm{CP}-011$ \\
\hline $\mathrm{KP}-011$ & $\mathrm{CP}-010, \mathrm{CP}-012$ \\
\hline $\mathrm{KP}-012$ & $\mathrm{CP}-008$ \\
\hline
\end{tabular}

TABEL V

PEMETAAN PRototipe TERHADAP USE CASE

\begin{tabular}{|l|l|}
\hline Use case Code & \multicolumn{1}{|c|}{ Prototype Code } \\
\hline UC -001 & CP-001 \\
\hline UC -002 & CP-002 \\
\hline UC -003 & CP-003, CP-004, CP-005, CP- \\
& 006, CP-007 \\
\hline UC -004 & CP-008 \\
\hline UC -005 & CP-010, CP-012 \\
\hline UC -006 & CP-009 \\
\hline UC -007 & CP-011 \\
\hline UC -008 & CP-012 \\
\hline UC -009 & CP-010, CP-012 \\
\hline UC -010 & CP-008 \\
\hline UC -011 & CP-010, CP-011 \\
\hline UC -012 & CP-010 \\
\hline UC -013 & CP-011 \\
\hline UC -014 & CP-011 \\
\hline
\end{tabular}

\section{KESIMPULAN}

Dalam penelitian ini model prototipe dan analisis use case berhasil diimplementasikan dalam proses rekayasa kebutuhan perangkat lunak pengajuan dokumen kependudukan. Model rekayasa kebutuhan dengan prototipe dilaksanakan secara iteratif dan harus melibatkan stakeholder internal organisasi yang terlibat didalam proses 
binsis, agar pengembang mampu menangkap kebutuhan pengguna yang spesifik dan berkualitas.

Pada proses rekayasa kebutuhan yang telah dilakukan, model prototipe sangat membantu pihak pengembang untuk menjelaskan kepada stakeholder berbagai hal teknis pada use case dengan adanya dukungan produk prototipe perangkat lunak yang dapat difungsikan oleh stakeholder. Stakeholder mampu memahami setiap fungsi dengan mudah, memberikan evaluasi dengan cepat dan model ini membantu pihak pengembang mendokumentasikan kebutuhan dengan cepat.

Proses rekayasa kebutuhan yang telah dilakukan menghasilkan 12 (dua belas) kebutuhan awal, 14 (empat belas) use case dan 12 (dua belas) prototipe. Prototipe berhasil dikembangkan berdasarkan 14 (empat belas) use case yang didefinisikan dan telah diuji cobakan kepada stakeholder. Berdasarkan pemetaan prototipe terhadap kebutuhan pengguna dan use case dengan traceability matrix, 12 (dua belas) prototipe yang dibangun berhasil dipetakan kedalam 12 (dua belas) kebutuhan pengguna dan kedalam 14 (empat belas) fungsionalitas yang didefinisikan pada use case. Disimpulkan bahwa seluruh prototipe telah memenuhi kebutuhan pengguna dan menghasilkan 14 (empat belas) spesifikasi kebutuhan fungsionalitas perangkat lunak pengajuan dokumen kependudukan. Spesifikasi kebutuhan perangkat lunak. dapat dijadikan acuan bagi pengembang untuk melakukan rekayasa atau implementasi produk perangkat lunak pengajuan dokumen kependudukan.

\section{REFERENSI}

[1] R.R. Young. 2004. The Requirements Engineering Handbook. Artech House, Inc. Boston, London.

[2] Y. Firmansyah, R. Maulana, D. Arivianti. 2019. Prototipe Sistem Informasi Pelelangan Barang Berbasis Web sebagai Media Pengolah Informasi Data Pelelangan. Jurnal Khatulistiwa Informatika, Vol. VII, No. 2 Bulan Desember 2019

[3] A. Mulyanto. 2009. Sistem Informasi Konsep dan Aplikasi. Yogyakarta. Pustaka Pelajar.

[4] R. M. Kimmond. 1995. Survey into the acceptance of prototyping in software development. Proceedings from the IEEE Sixth International Workshop on Rapid System Prototyping, 147-152.

[5] I. Sommerville. 2016. Software Engineering, 10th Edition. England, Pearson Education Limited.

[6] Undang-Undang Nomor 23 Tahun 2006 Bab VI Bagian Kedua Pasal 59 Ayat 1 Tentang Dokumen Kependudukan.

[7] M. Mannio, U. Nikula. 2001. Requirements Elicitation Using a Combination of Prototypes and Scenarios. Telecom Business Research Center Lappeenranta Research Report 5.

[8] S. Sauda, E.P. Agustini. 2020. Implementasi Prototype Model dalam Pengembangan Aplikasi Smart Cleaning Sebagai Pendukung Aplikasi Smart City. Jurnal Manajemen, Teknik Informatika dan Rekayasa Komputer Vol. 20, No. 1, November 2020, pp. 73 84.

[9] R.S. Pressman. 2010. Software Engineering a Practitioner's Approach 7th Edition. McGraw Hill Higher Education.

[10] K. Wiegers, J. Beatty. 2013. Software Requirements, Third Edition. Microsoft Press, A Division of Microsoft Corporation, One Microsoft Way. Redmond, Washington.

[11] R. Miles, K. Hamilton. 2006. Learning UML 2.0. O’Reilly.

[12] Y. Syafitri. 2016. Analisa dan Perancangan Berbasis UML pada Sistem Informasi Simpan Pinjam Koperasi Swamitra Bandar Lampung. Jurnal Informasi dan Komputer, vol. 4, no. 1, pp. 22-31, Oct. 2016.
[13] A. Susanto, Meiryani. 2019. System Development Method with The Prototype Method. International Journal of Scientific \& Technology Research Volume 8, Issue 07, July 2019.

[14] S. Sismadi. 2021. Penerapan Model Prototipe Aplikasi Perangkat Lunak Pemesanan Air Bersih Pdam Tirta Pakuan Kota Bogor. Inti Nusa Mandiri, 15(2), 119-126.

[15] F. Shabrina, Widodo, B.P. Adhi. 2020. Model Requirement Traceability untuk Metode Pengembangan Perangkat Lunak Feature Driven Development (FDD). Seminar Nasional Informatika (SEMNASIF) 2020, Vol.1, No.1, 26 November 2020, hlm 230-240.

[16] S.A. Hanansyah, W. Purnomo, Kariyoto. 2020. Analisis dan Perancangan Sistem Informasi Akademik dan Keuangan TK Tunas Bangsa. Jurnal Pengembangan Teknologi Informasi dan Ilmu Komputer Vol. 4, No. 8, Agustus 2020, hlm. 2599-2607. 